\title{
実規模供試体による温度応力抑制工法の実証実験
}

\section{THE EXPERIMENTAL OBSERVATIONS OF THE THERMAL STRESS REDUCTION METHOD ON ACTUAL SIZE SPECIMENS}

\author{
横田季彦*·竹下治之** \\ By Suehiko YOKOTA and Haruyuki TAKESHITA
}

\begin{abstract}
This paper discribes the method that places set-retarded concrete between alreadeyplaced concrete and newly-placed one in order to reduce thermal stress in the vicinity of construction joints of massive concrete. The purpose of this study is to prove the effect of the method. The experimental study is performed with two actual size $20 \mathrm{~m}$ long specimens, a conventional concreting method and this new one. It is found to be particulaly effective in reducing temperature gradient of newly-placed concrete, decreasing the ratio of restriction and reducing thermal stress and to be able to prevent thoroughly occurrance of cracks in newly-placed concrete by use of this new method.

Keywords : set-retarded concrete, thermal stress, the ratio of restriction, temperature gradient, crack, construction joints
\end{abstract}

\section{1. まえがき}

旧コンクリートや岩盤上に新コンクリートを打ち継ぐ 場合, 新コンクリートの温度変化に伴う体積変化が, 旧 コンクリートや岩盤により外的に拘束を受け, 新コンク リートにひびわれが生じることがある.このひびわれは, 温度ひびわれのうちの外部拘束ひびわれとよばれるもの であり,壁式コンクリート構造物を施工後比較的初期に, 壁部コンクリートにおいて多くみられるものである.

この壁部コンクリートに発生する外部拘束ひびわれの 多くは貫通ひびわれとなるため, 単に美観上の問題とな るだけでなく, コンクリート構造物の強度, 耐久性およ び水密性, 気密性などの点からも大きな欠陥となる. 特 に, 貯水槽をはじめとする各種の貯蔵施設では, 壁部に 発生したひびわれが漏水など内部物質の漏洩の原因とな るため，その補修に多額の費用を要することになる.

著者らは，このような現状に対して，外部拘束ひびわ れを防止する方法として, 新旧コンクリートの打継部に 凝結遅延剂（以下, 遅延剂と記す）を添加した凝結遅延
性コンクリート（以下，遅延コンクリートと記す）を 10〜20 cm 打設し，この未硬化コンクリートの緩衝作用 によって, 外部拘束応力を緩和し, ひびわれの発生を防 止する温度応力抑制工法に関して，その抑制メカ二ズム と, 比較的小規模な供試体を用いて行った実験について 報告した ${ }^{11,21}$ が，実構造物に適用するためには，さらに 検討の余地があることがわかった。そこで，本論文では， この温度応力抑制工法を実構造物に適用した場合の効果 を実証することを目的として行った, 長さ $20 \mathrm{~m}$ の実規 模供試体による実証実験の結果について報告する.

\section{2. 実 験 概 要}

\section{（1）配合および使用材料}

実験に使用したコンクリートの配合を表一1に示す. 表中の配合 $\mathrm{A}$ は通常コンクリート部に使用した配合であ り, 流動化剂を現場添加しスランプを $18 \mathrm{~cm}$ として使 用した。一方, 配合 B は遅延コンクリート製造のための ベースコンクリートの配合であり, 遅延剤の添加による

$$
\text { 表一1 配 合 }
$$

* 正会員 日本国土開発 (株) 技術研究所 ( ( 243-03 神奈川県愛甲郡愛川町中津 4036-1)

** 正会員 工博 日本国土開発 (株) 技術研究所コンクリ卜研究室長 (同上)

\begin{tabular}{|c|c|c|c|c|c|c|c|c|c|c|c|}
\hline \multirow{2}{*}{\begin{tabular}{|l|} 
Ri合 \\
No.
\end{tabular}} & \multirow{2}{*}{ 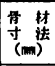 } & \multirow{2}{*}{ 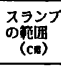 } & \multirow{2}{*}{ 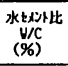 } & \multirow{2}{*}{ 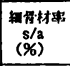 } & \multicolumn{7}{|c|}{ 监 $\left(\mathrm{kg} / \mathrm{m}^{3}\right)$} \\
\hline & & & & & 水 & $t x j$ & 纰骨材 & 柤骨材 & AE墄水斉 & 㙋粘䘞 & 建延副 \\
\hline $\mathrm{A}$ & 25 & $12 \pm 2.5$ & 48.9 & 78 & 157 & 321 & 858 & 984 & 0.802 & - & \\
\hline B & 25 & $8 \pm 1.0$ & 46.0 & 43 & 144 & 313 & 818 & 1066 & 0.782 & 0.5 & 2.19 \\
\hline
\end{tabular}


表一2 使用材料

\begin{tabular}{|c|c|c|c|}
\hline セメント & \multicolumn{3}{|c|}{ 普通ポルトランドセメント } \\
\hline 緗骨材 & \multicolumn{3}{|c|}{ 相棋川水系 $80 \%$ 、市川産川尖20\%（比重2.60、FM2.06） } \\
\hline 粗 骨 材 & \multicolumn{3}{|c|}{ 相模川水系 $40 \%$ 、津久井産碎石 $60 \%$ （此重2.65、FM6.80） } \\
\hline AE娍水都 & リグニンスルホン酸系 & 暒延绪 & オキシカルボン酸監系 \\
\hline 为化剖 & メラミンスルホン酸系 & 增粘谪 & セル \\
\hline
\end{tabular}

スランプの増加を考慮し，配合 $\mathrm{A}$ に対してスランプを小 さくし，ブリージングを防止する目的で増粘剤を使用す るとともに, 打継部の十分な強度を保証するため水セメ ント比を通常コンクリートに比べ幾分小さくした. 表一 2 に使用材料を示す.

\section{(2) 実験供試体}

実験供試体は, 図一1に示すように貯蔵施設の一部を モデル化したL形㩁壁モデルであり, 底版部の旧コンク リートにより壁部の新コンクリートが拘束を受けるもの である. 実験供試体は 2 体作製し， 1 体を温度応力抑制 工法を適用して打継ぎを行ったもの（以下，抑制供試体 と記す)，他の 1 体を通常の打継ぎを行ったもの（以下， 通常供試体と記す) とし, 両者を比較検討した.

供試体の作製方法としては，まず底版部コンクリート を打設し, 打継部に遅延剤を散布して表面処理を行い, 底版部コンクリート打設後約 2 か月で壁部コンクリート を打設した。

\section{（３）遅延コンクリートの製造}

a) 温度履歴の予測：遅延コンクリートを用いた温度 応力抑制工法では, 対象とする構造物の温度履歴を把握 し, 遅延コンクリートの凝結速度を適切にコントロール することが重要となる。このため, 実験供試体の打設時 期, 配合, 使用型枠の材質などをもとに, 実験供試体の 壁部コンクリートの温度解析を行った。この結果, 実験 供試体の壁部コンクリートは材令約 0.8 日で最高温度と なり, 温度変化量は約 $23^{\circ} \mathrm{C}$ となることが推定された。

この結果から, 実験供試体の打継部に打設する遅延コ ンクリートは, 打設直後から最高温度到達時までの期間, 平均温度 $40^{\circ} \mathrm{C}$ 程度の養生条件下におかれるものと推定 される.したがって, 養生温度を $40^{\circ} \mathrm{C}$ および $30^{\circ} \mathrm{C}$ の 2 種類として, 遅延コンクリートの凝結特性試験を行い, 遅延コンクリート製造のための遅延剂添加量を決定した。

b) 遅延コンクリートの凝結特性予備試験：底版部コ ンクリート上に打設する壁部コンクリートは, 打設後最 高温度に達するまで膨張し, その後の温度降下とともに 収縮過程に移行する。したがって, 壁部コンクリートの 変形に対する拘束を䋧和するためには, 打継部の遅延コ ンクリートは, 壁部コンクリートが収縮する時期におい ても十分な変形能力を有する必要がある. 著者らがこれ

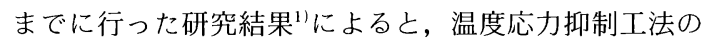

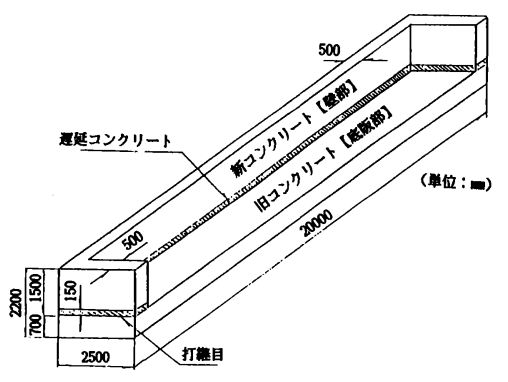

図一1 実験供試体の概要

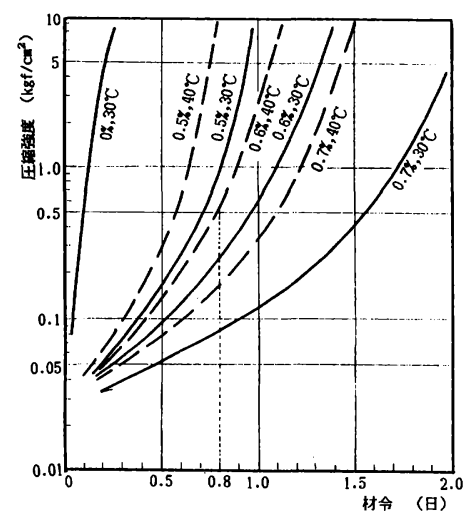

図一2 遅延コンクリートの凝結特性

適用による発生応力の低減率を $50 \%$ とするためには, 最高温度時における遅延コンクリートの目標圧縮強度は 約 $0.85 \mathrm{kgf} / \mathrm{cm}^{2}$ とすればよい.

図一2 は, 本実験に先立ちあらかじめ行った養生温度 $30^{\circ} \mathrm{C}$ おび $40^{\circ} \mathrm{C}$ での遅延コンクリートの凝結特性を 示したものである. 同図から, 養生温度 $40^{\circ} \mathrm{C} て ゙$, 材令 0.8 日においてこの目標圧縮強度を達成する遅延剂の添 加量は約 $0.6 \%$ (セメント重量に対して) となるが, 本 実験では前述した温度履歴の推定誤差およびひびわれ防 止に対する安全性を考慮し, 添加量は $0.7 \%$ とした。

c）遅延コンクリート打設時の留意点: 遅延コンク リートの製造に生コンクリートを使用する場合, 直前に 異種のセメントが使用されていると，この影響を受けて 遅延コンクリートの凝結特性がかなり変化する場合があ る.このため, 遅延コンクリートの製造に際しては, 生 コン工場のプラントの設備状況を考慮し, 必要に応じて 捨てバッチを行うこととした.

また, 本温度応力抑制工法において遅延コンクリート の層厚を均等に打設することは, 美観上のみならず所要 の抑制効果を得るためにも重要な問題である.このため, 遅延コンクリート製造時のベースコンクリートのスラン プを幾分小さくし，引き続き打設する通常コンクリート のスランプを流動化羭により若干大きくするとともに， 図一3に示すような治具をコンクリートポンプのホース 


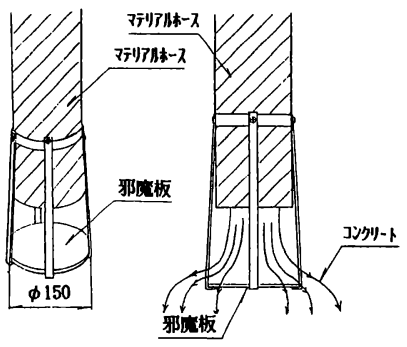

図一３遅延コンクリート打設用治具

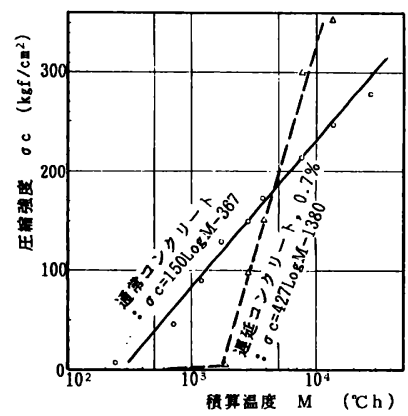

図一4 遅延コンクリートの圧縮強度と 積算温度との関係

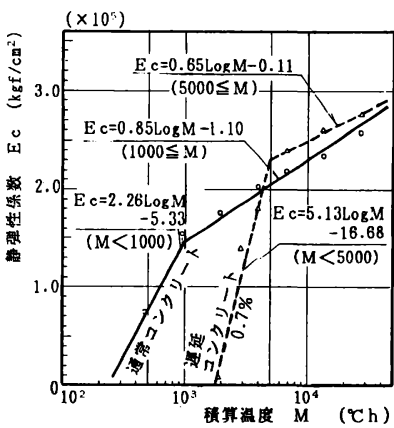

図一5 遅延コンクリートの静弾性係数と 積算温度との関係

の先端に取り付け, 通常コンクリートが直接落下し遅延 コンクリート中に浸入するのを防止した。

d）遅延コンクリートの物性值：図一4 は, 前述した 凝結特性試験の結果をもとに，遅延剂の添加量を $0.7 \%$ とした場合の遅延コンクリートの圧縮強度と積算温度と の関係を，通常コンクリートのそれとともに示したもの である。なお，積算温度は養生温度 $\left(30^{\circ} \mathrm{C}\right.$ または $\left.40^{\circ} \mathrm{C}\right)$ と養生期間（載荷材令）とから次式によって算定した。

積算温度 $\quad M=\sum(10+T) \cdot t \cdots \cdots \cdots \cdots \cdots \cdots \cdots \cdots \cdots \cdots(1)$ ここに, $T$ : 養生期間 $\left({ }^{\circ} \mathrm{C}\right), t: T^{\circ} \mathrm{C}$ での養生期間 $(\mathrm{h})$ 同図に示されるように，積算温度が約 $5000^{\circ} \mathrm{C} \mathrm{h}$ 以上 の範囲では, 遅延コンクリートの圧縮強度は通常コンク リートのそれ以上となることがわかる。これは遅延コン クリート製造時のベースコンクリートの水セメント比が 通常コンクリートのそれに比べて幾分小さいこと, 遅延 剤の添加によりセメントの水和反応が緩やかに進行する ため，密実なコンクリートが形成されることによるもの であり ${ }^{3 /, 41}$, この結果から, 打継部に打設する遅延コン クリートが構造上の弱点とならないことがわかる.また， 遅延コンクリートの圧縮強度は, ある強度以上の範囲に おいて, 通常コンクリートと同様に, 積算温度の対数值 をパラメーターとして直線で近似できることがわかる.

図一5 は, 遅延コンクリートの静弾性係数を積算温度 を用いて整理したものである.同図から, 遅延コンクリー トおよび通常コンクリートの静弾性係数は, 積算温度が ある值となった時点を変曲点として，それぞれほぼ 2 本 の直線によって近似できることがわかる.

\section{(4) 計 測 概 要}

a) 計測器埋設位置: 実験供試体の計測器埋設位置を 図一6に示す．同図に示すように，実験供試体の中央部 を断面(1), 全長の $1 / 4$ の位置を断面(2), 端部から $1 \mathrm{~m}$ の位置を断面(3)して，これらの各断面の打継目から 25, 75 および $125 \mathrm{~cm}$ の高さ方向 3 段にひずみ計および 温度計を設置した。

また，両供試体の各計測断面の中段部（打継目から $75 \mathrm{~cm})$ にコンクリート応力計を設置するとともに, 通
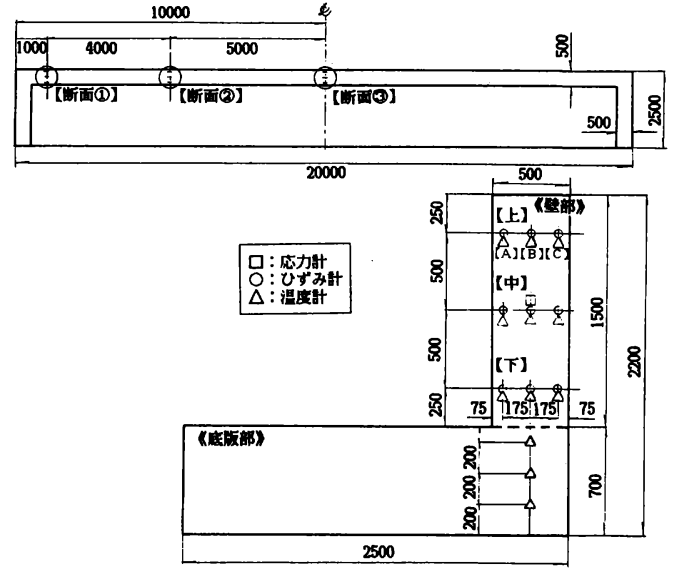

図一6 実験供試体の計測器埋設位置

常供試体の壁部に無応力計を設置し，使用コンクリート の熱膨張係数を測定した.

b）新旧コンクリートの相対変位: 本実験供試体のよ うに, 部材断面に対して比較的寸法が長い構造物では, 新旧コンクリート間に相対変位が生じる可能性があ $ろ^{5 !}$. 特に, 本温度応力抑制工法を適用した場合, 旧コ ンクリートの拘束が大きく緩和されるため, 実験供試体 の端部ではかなりの相対変位が生じることが考えられ る.このため, 実験供試体の端部の高さおよび長さ方向 の 2 方向に高感度変位計を取り付け, 壁部コンクリート 打設後の相対変位を計測した。

c）コアボーリング：本温度応力抑制工法を適用した 場合の打継部の一体性を検討するため, 計測終了後, 図 一7に示す 3 断面においてコアボーリングを行い，透水 試験および打継強度試験用のテストピースを採取した。

\section{3. 実験結果および考察}

\section{（1）打設初期の温度応力に対する検討}

a) コンクリートの温度：通常供試体および抑制供試 体のコンクリート温度の経時変化の一例として, 両供試 体の断面(1)（中央部）の中段部における計測結果を図一 
8 および図一9に示す。また，各計測位置のコンクリー 卜温度の計測結果をもとに整理した温度特性を表一 3 に 示す.

これらの図表に示されるように，壁部のコンクリート 温度は材令 $0.50 \sim 0.69$ 日で最高温度となった後, 材令 4 日程度までは急速に降下し, その後材令約 10 日程度 で外気温とほぼ同等となった。 また, 最高温度到達材令 が前述した予測值の 0.8 日に比べて幾分早くなった原因 としては，コンクリートの打設温度を $27^{\circ} \mathrm{C}$ 仮定した のに対し，実際は約 $31^{\circ} \mathrm{C}$ と高かったことが考えられる.

また，抑制供試体と通常供試体の温度履歴を比較した 場合，抑制供試体では打継部に打設した遅延コンクリー トの影響によって，全体的にコンクリート温度が若干小 さくなっているほか, 温度降下速度も小さくなっている. すなわち, 最高温度時から材令 4 日までの温度降下速度 は, 通常供試体で $7.85 \sim 8.17^{\circ} \mathrm{C} /$ 日, 抑制供試体で 7. $31 \sim 7.63^{\circ} \mathrm{C} /$ 日である. この温度降下速度は壁部に 発生する温度応力に大きく影響を及ぼすものであり, 温 度复歴からも本温度応力抑制工法の効果が期待できる.

b) コンクリートの熱膨張係数：無応力計における見 掛けひずみと温度変化量の関係を図一10に示す. 同図 から，使用コンクリートの熱膨張係数は両者の傾きとし て, 以下のように求められる.

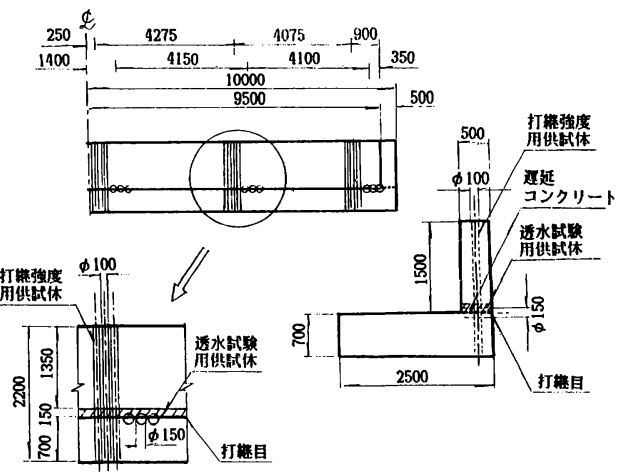

図一7 コアボーリング位置

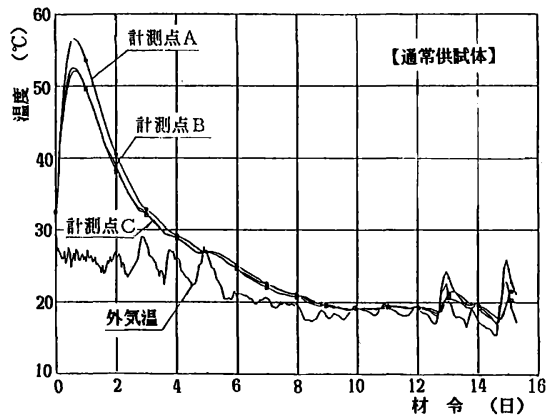

図一8 通常供試体におけるコンクリート温度の 経時変化

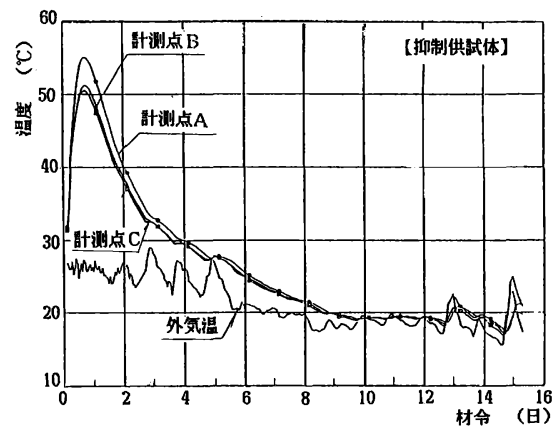

図一9抑制供試体におけるコンクリート温度の経時変化

・温度上昇時…… $8.60 \times 10^{-6} /{ }^{\circ} \mathrm{C}$

・温度下降時……10.06 $01010^{-6} /{ }^{\circ} \mathrm{C}$

c）拘 束 度：一般に, コンクリート構造物の各計 測位置での拘束度は，温度変化量と見掛けひずみとの関 係から，両者の直線の傾きとして求めた見掛けひずみ変 化率を用いて次式によって算定することができる ${ }^{6)}$.

拘束度 $K=\left(\alpha_{f}-\alpha_{r}\right) / \alpha_{f}$ $\cdot(2)$

ここに, $\alpha_{f}$ : コンクリートの熱膨張係数 $\left({ }^{\circ} \mathrm{C}^{-1}\right)$

$\alpha_{r}:$ 各計測位置の見掛けひずみ変化率 $\left({ }^{\circ} \mathrm{C}^{-1}\right)$

表一4に両供試体の各計測位置での拘束度の算定結果 を，図一11 に両供試体の高さ方向の拘束度の分布を， 図一12 に長さ方向の拘束度の分布を示す．なお，温度 上昇時はコンクリート打設時から最高温度時まで，温度 下降時は最高温度時から材令 5 日までの平均的な拘束度 を示したものである。

これらの図表に示されるように，抑制供試体の拘束度 は, 温度上昇時および温度下降時とも通常供試体のそれ に比べて小さくなっている，いま，同一位置での両供試 体の拘束度比を算定すれば，温度上昇時および温度下降 時において, 全計測位置の平均值で 0.31 および 0.50 上 なっており, 本温度応力抑制工法の適用により, 壁部の 拘束度は 50 ～70\% 低減されていることがわかる。

表一3 実験供試体の温度特性

\begin{tabular}{|c|c|c|c|c|c|c|c|c|c|}
\hline 晎约体 & Ht䊁断面 & 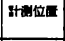 & 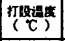 & $(\mathrm{C})$ & 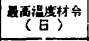 & 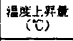 & 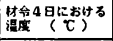 & $\frac{{ }^{3}}{(\tau)}$ & 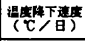 \\
\hline \multirow{9}{*}{ 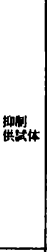 } & \multirow{3}{*}{ 断面 (1) } & 上 & 30.6 & 49.0 & 0.50 & 18.4 & 28.1 & 20.8 & 5.97 \\
\hline & & 中 & 31.0 & 55.1 & 0.67 & 24.1 & 29.9 & 25.2 & 7.54 \\
\hline & & $T$ & 30.6 & 44.2 & 0.63 & 13.6 & 30.2 & 14.0 & 4.15 \\
\hline & \multirow{3}{*}{ 断面 (2) } & 上 & 30.1 & 47.4 & 0.56 & 17.3 & 28.0 & 19.4 & 5.64 \\
\hline & & 中 & 30.8 & 55.0 & 0.67 & 24.2 & 29.6 & 25.4 & 7.63 \\
\hline & & $T$ & 30.5 & 46.5 & 0.58 & 16.0 & 30.1 & 18.4 & 4.80 \\
\hline & \multirow{3}{*}{ 斷面 } & 上 & 30.3 & 47.9 & 0.52 & 17.6 & 28.0 & 18.9 & 5.72 \\
\hline & & 中 & 31.0 & 54.4 & 0.66 & 23.4 & 30.0 & 24.4 & 7.31 \\
\hline & & $T$ & 30.6 & 44.4 & 0.63 & 13.8 & 30.4 & 14.0 & 4.15 \\
\hline \multirow{9}{*}{ 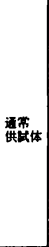 } & \multirow{3}{*}{ 断面 (1) } & 上 & 30.9 & 48.6 & 0.51 & 17.7 & 27.9 & 20.7 & 5.93 \\
\hline & & 中 & 31.7 & 56.6 & 0.68 & 24.9 & 29.3 & 27.3 & 8.17 \\
\hline & & $T$ & 31.7 & 53.0 & 0.60 & 21.3 & 30.1 & 22.9 & 6.73 \\
\hline & \multirow{3}{*}{ 断面 (2) } & 上 & 31.4 & 48.5 & 0.61 & 17.1 & 28.1 & 20.4 & 6.02 \\
\hline & & 中 & 31.9 & 56.5 & 0.69 & 24.6 & 29.6 & 26.9 & 8.13 \\
\hline & & $F$ & 31.5 & 52.1 & 0.58 & 20.6 & 29.0 & 23.1 & 6.75 \\
\hline & \multirow{3}{*}{ 䉼面 (2) } & 上 & 30.8 & 48.9 & 0.60 & 18.1 & 28.4 & 20.5 & 6.03 \\
\hline & & 中 & 30.7 & 55.8 & 0.69 & 25.2 & 29.9 & 26.0 & 7.85 \\
\hline & & $T$ & 30.4 & 50.5 & 0.63 & 20.1 & 20.2 & 21.3 & 6.32 \\
\hline
\end{tabular}




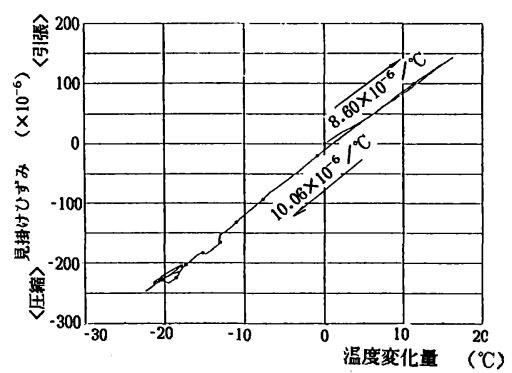

図一10＼cjkstart熱膨張係数測定における見掛けひずみと 温度変化量との関係

表一4 拘束度の算定結果

\begin{tabular}{|c|c|c|c|c|c|c|c|c|}
\hline \multirow{2}{*}{\multicolumn{3}{|c|}{ 㽖测位琶 }} & \multicolumn{2}{|c|}{ 温度上界時 } & \multicolumn{2}{|c|}{ 温度下㥪時 } & \multicolumn{2}{|c|}{ Uとわれ觉生後 } \\
\hline & & & 拍東度 & 拘束度比 & 拘束度 & 拘東度比 & 抽東度 & 拘束度比 \\
\hline \multirow{3}{*}{ 通 } & \multirow{3}{*}{ 䉼面(1) } & 上 & 0.624 & - & 0.399 & - & 0.146 & - \\
\hline & & 巾 & 0.726 & - & 0.634 & - & 0.295 & -- \\
\hline & & F & 0.788 & - & 0.684 & - & 0.425 & - \\
\hline 常 & & 上 & 0.635 & - & 0.185 & - & 0 & - \\
\hline \multirow[t]{2}{*}{ 供 } & 断面(2) & 中 & 0.686 & - & 0.429 & - & 0.086 & - \\
\hline & & $T$ & 0.702 & - & 0.604 & - & 0.279 & - \\
\hline 证 & & 上 & 0.306 & - & 0 & - & 0.010 & - \\
\hline \multirow[t]{2}{*}{ 林 } & 断面(3) & 中 & 0.420 & - & 0.175 & - & 0.003 & - \\
\hline & & $F$ & 0.455 & - & 0.359 & - & 0.192 & - \\
\hline \multirow{3}{*}{ 抑 } & \multirow{3}{*}{ 断面(1) } & 上 & 0.227 & 0.364 & 0.040 & 0.100 & $-\ldots$ & - \\
\hline & & 中 & 0.353 & 0.486 & 0.295 & 0.465 & 一 & - \\
\hline & & 下 & 0.028 & 0.036 & 0.399 & 0.583 & - & - \\
\hline 制 & & 上 & 0.208 & 0.328 & 0.003 & 0.016 & - & - \\
\hline \multirow[t]{2}{*}{ 供 } & 断面(2) & 中 & 0.294 & 0.429 & 0.272 & 0.634 & - & - \\
\hline & & 下 & 0.118 & 0.168 & 0.389 & 0.644 & - & - \\
\hline 拭 & \multirow{3}{*}{ 断面(3) } & 上 & 0.126 & 0.418 & 0 & - & - & - \\
\hline \multirow[t]{2}{*}{ 休 } & & 中 & 0.224 & 0.533 & 0.120 & 0.684 & - & - \\
\hline & & F & o & 0 & 0.235 & 0.654 & - & - \\
\hline & & & 平均圆 & 0.307 & 平均幅 & 0.496 & - & - \\
\hline
\end{tabular}

また，通常供試体の拘束度の分布は，打継目に近いほ よ゙，また中央部に近いほよ゙大きくなる傾向にある。一般 的に，壁式コンクリート構造物においてひびわれが発生 しやすい位置は，部材の中央部の打継目近傍であり ${ }^{7)}$, 拘束度が最大となる位置でひびわれが発生する可能性が 高いことを示している.

d) コンクリートの有効弾性係数：コンクリート構造 物に発生する温度応力は, 若材令で比較的大きな応力を 発生して，その後も長期にわたり作用する。このため, 実験供試体に発生する温度応力を評価する場合, クリ一 プによる剛性の低下を考慮した有効弾性係数を用いる必 要がある.この有効弾性係数は, 通常 $0.5 \sim 0.6$ の值を 用いるが，本実験では，式（3）から算定できる応力ひ ずみとコンクリート応力計によって計測された応力とを 用い，両者の微小区間での傾きとして式（4）により算 定した ${ }^{81}$. 応力ひずみと応力との関係の一例として, 通常 供試体の断面(1)の中段部での測定結果を図一13 に示す.

応力ひずみ $\varepsilon_{e}=\varepsilon_{m}-\varepsilon_{f}=\varepsilon_{m}-\Delta T \cdot \alpha_{c}$

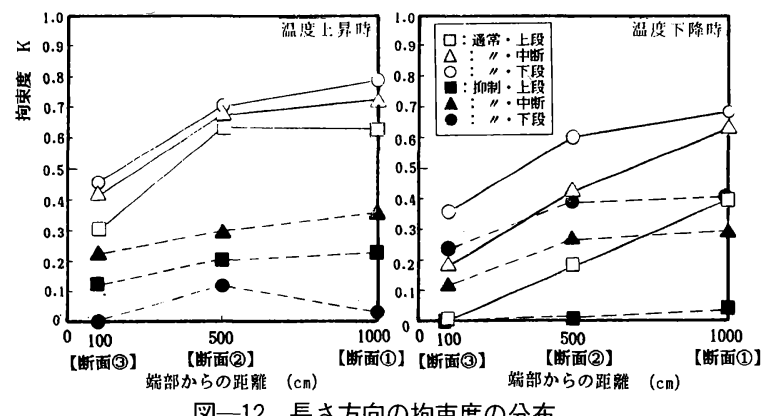

図一12 長さ方向の拘束度の分布

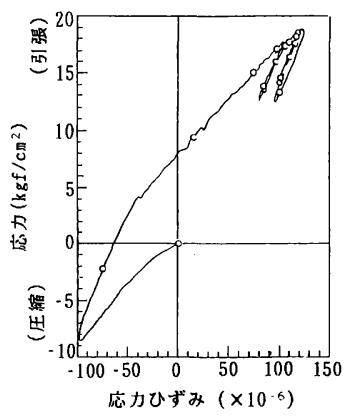

図一13 通常供試体における応力と応力ひずみとの関係

ここに, $\varepsilon_{m}$ : コンクリートの見掛けひずみ

$\varepsilon_{f}:$ コンクリートの自由変形ひずみ

$\Delta T:$ コンクリトの温度変化量 $\left({ }^{\circ} \mathrm{C}\right)$

$\alpha_{c}$ : コンクリートの熱膨張係数 $\left({ }^{\circ} \mathrm{C}^{-1}\right)$

有効弾性係数 $E_{e}=\Delta \sigma / \Delta \varepsilon_{e}$

ここに, $\Delta \sigma$ : 応力の増分 $\left(\mathrm{kgf} / \mathrm{cm}^{2}\right)$

$\Delta \varepsilon_{e}$ : 応力ひずみの増分

式（4）から算定した通常供試体および抑制供試体の 有効弾性係数の経時変化を, 図一14 および図一15に示 す。これらの図中には，実験供試体のコンクリート温度 の実測値をもとに算定した積算温度から，図一 5 中の通 常コンクリートの式より算定した静弾性係数も併せて示 す.これらの図に示されるように, 実験供試体中の各断 面における有効弾性係数は同一供試体でもその計測位置 によって異なっており，拘束状態の影響を大きく受けて いることがわかる.これらの有効弾性係数は, 温度応力 が急変するコンクリート打設初期では不安定な挙動を示 


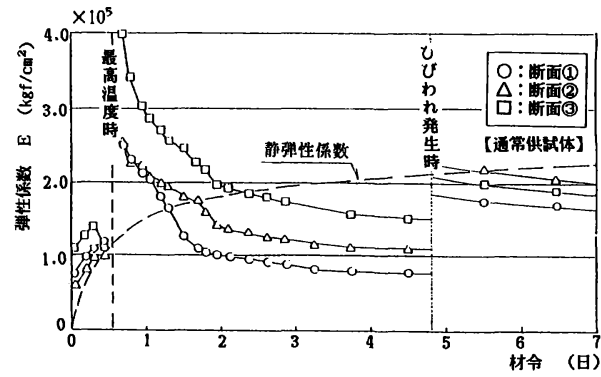

図一14 通常供試体における有効弾性係数の経時変化

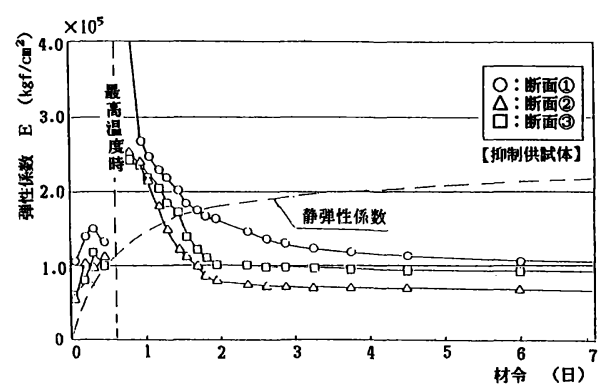

図一15抑制供試体における有効弾性係数の経時変化

すが，著者らの研究によれば9)，この時期の值は，計測 上および算定上の誤差の影響を大きく受ける. 有効弾性 係数は, その後, 温度が降下するのに従い急速に小さく なり，温度の安定とともにほぼ一定值となっている。ま た, 通常供試体ではひびわれが発生すると, 一度安定し た有効弾性係数が再び大きく変動している．これは，ひ びわれが発生することにより応力が緩和され，クリープ ひずみが小さくなるため, 有効弾性係数が大きくなるも のと考えられる.

このようなコンクリートのクリープによる剛性低下を 検討するため, 次式により弾性係数低減率を求めた。図 一16および図一17に算定結果を示す.

弾性係数低減率 $R=E_{e} / E_{c}$

ここに, $E_{e}$ : コンクリートの有効弾性係数 $\left(\mathrm{kgf} / \mathrm{cm}^{2}\right)$

$E_{c}$ : コンクリートの静弾性係数 $\left(\mathrm{kgf} / \mathrm{cm}^{2}\right)$

これらの図から，弾性係数低減率がほぼ一定となった 值を定数 $C_{2}$, ひびわれ発生後の值を $C_{2}^{\prime}$ として, これ らの拘束度との関係を図一18に示す。

同図から，通常供試体の定数 $C_{2}, C_{2}^{\prime}$ はひびわれ発生 の前後で大きく変動するのにもかかわらず，拘束度とほ ぼ直線関係にあることがわかる，すなわち，前述したよ うに拘束度が大きくなると発生応力も大きくなり，ク リープひずみが増大するため有効弾性係数が小さくな る.したがって，クリープによる剛性低下の割合を示す 定数 $C_{2}, C_{2}^{\prime}$ が小さくなるものと考えられる.

一般に，コンクリートのクリープの多少に影響を及ぼ す要因は応力レベル，応力の載荷材令，環境および配合

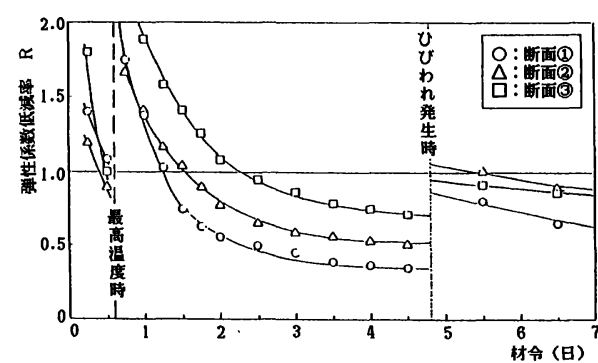

図一16 通常供試体における弾性係数低隇率の経時変化

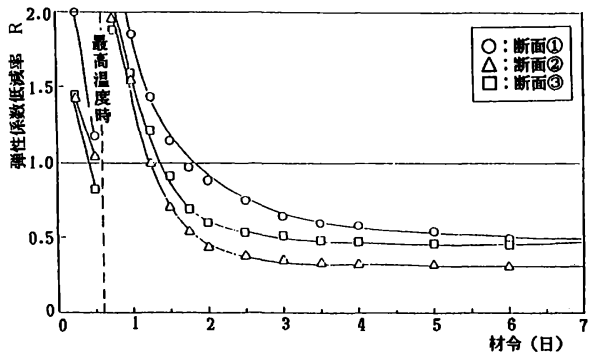

図一17抑制供試体における弾性係数低減率の経時変化

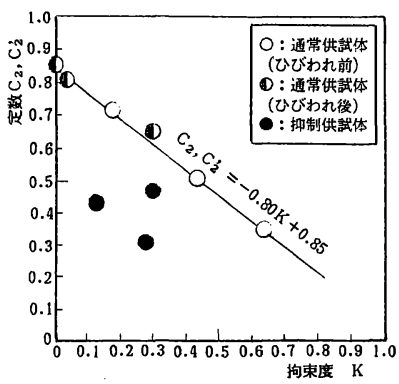

図-18 定数 $C_{2}, C_{2}^{\prime}$ と拘束度との関係

であり，これらの関係を示すと図一19のようである. すなわち, 弾性係数低減率が発生応力レベル, 最高温度 到達材令，養生状態および配合によって定まるものと考 えられる，また，本実験での通常供試体の各計測位置に 限れば，発生応力レベル以外の要因がほぼ同一であるた め, 発生応力の大小, すなわち拘束度の大小によって弾 性係数低減率が決定されるものと考えられる。この弾性 係数低減率を応力解析に反映させることを目的として検 討を行った結果 ${ }^{10)}$, 最高温度時までの不安定な値を示す 区間を 1.0 とし，これから温度安定時までの区間を 2 次 式に，それ以降の温度安定時期を定数 $C_{2}$ として近似す ることにより比較的都合良くモデル化することができ $3^{91}$. また，本実験の通常供試体の場合は，図一20に示 すように，ひびわれ発生後をさらに定数 $C_{3}$ とすること によってモデル化できる，表-5 は，図-18 および，拘 束度の算定結果加, 通常供試体の定数 $C_{1}, C_{2}, C_{2}^{\prime}$ を 算定したものである。

e）コンクリートの発生応力：前述した応力ひずみお 


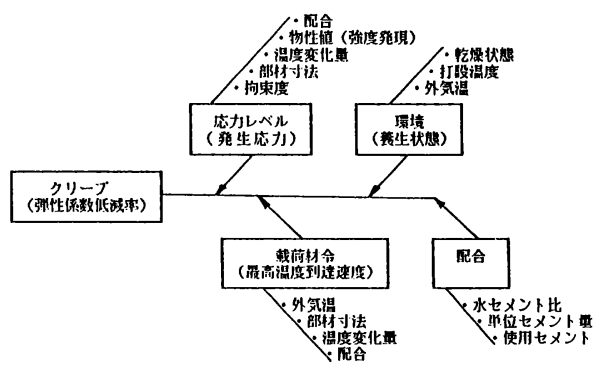

図一19 クリープ（弾性係数低減率）に影響を及ぼす要因

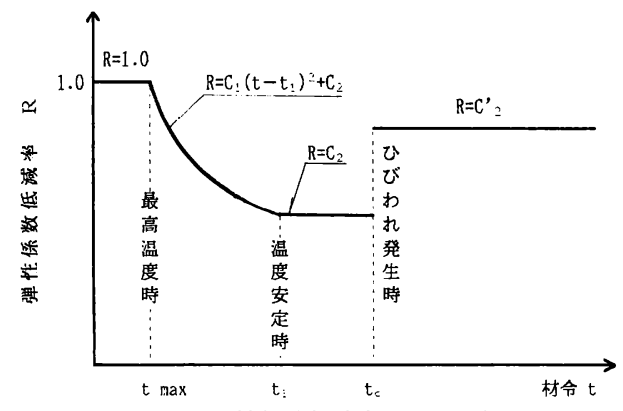

図一20 弾性係数低減率のモデル化

表一5 通常供試体における定数 $C_{1}, C_{2}, C_{2}^{\prime}$

\begin{tabular}{|c|c|c|c|c|}
\hline \multicolumn{2}{|c|}{ 旪测位卧 } & $C_{1}$ & $\mathrm{C}_{2}$ & $\mathrm{C}_{2}$ \\
\hline \multirow{3}{*}{ 断面(1) } & 上 & 0.038 & 0.53 & 0.73 \\
\hline & 中 & 0.060 & 0.34 & 0.61 \\
\hline & 下 & 0.062 & 0.30 & 0.51 \\
\hline \multirow{3}{*}{ 断面(2) } & 上 & 0.025 & 0.70 & 0.85 \\
\hline & 中 & 0.044 & 0.51 & 0.78 \\
\hline & 下 & 0.054 & 0.37 & 0.63 \\
\hline \multirow{3}{*}{ 断面(3) } & 上 & 0.012 & 0.85 & 0.84 \\
\hline & 中 & 0.026 & 0.71 & 0.85 \\
\hline & 下 & 0.039 & 0.56 & 0.70 \\
\hline
\end{tabular}

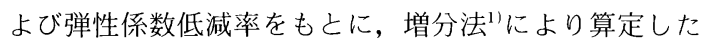
発生応力の算定結果を表一6に示す。また,これらの発 生応力の経時変化の一例として, 両供試体の断面(2)の中 段部における応力変化を図一 21 に, 両供試体の応力分 布を図一22 および図一23に示す。

これらの図表から, 通常供試体の場合は打設初期を除 き, 中央部から供試体長さの $1 / 4$ 地点までの打継目近傍 で最大引張応力が発生しており, 前述した拘束度の分布 状況も併せて考えれば，この位置でひびわれが発生しや すい状況にあることがわかる，このような傾向は, 壁式 コンクリート構造物のひびわれ発生状況の典型的なもの であり，本実験では発生応力および拘束度の両面から， このような傾向を明らかにすることができた．また，実 験供試体の引張応力は, 端部および上段部に近いほゼ小 さくなり，端部の上段部では圧縮応力が発生している.

一方, 抑制供試体においては, 通常供試体に比べて全
表一6 発生応力の算定結果

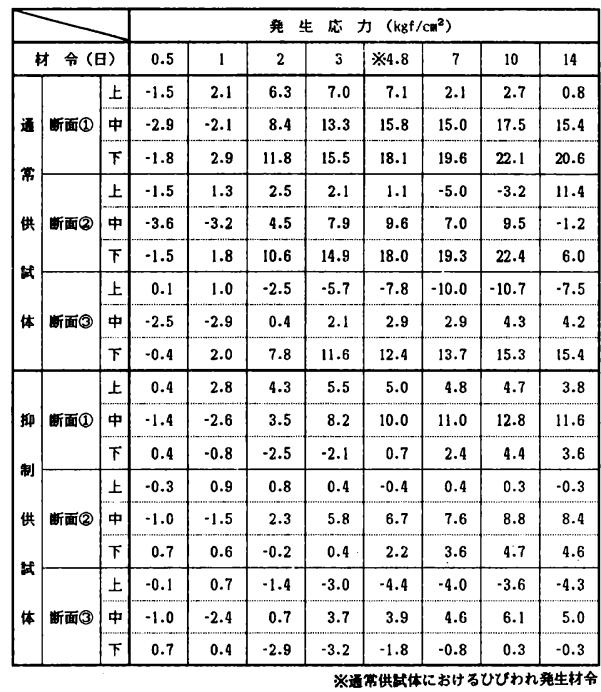

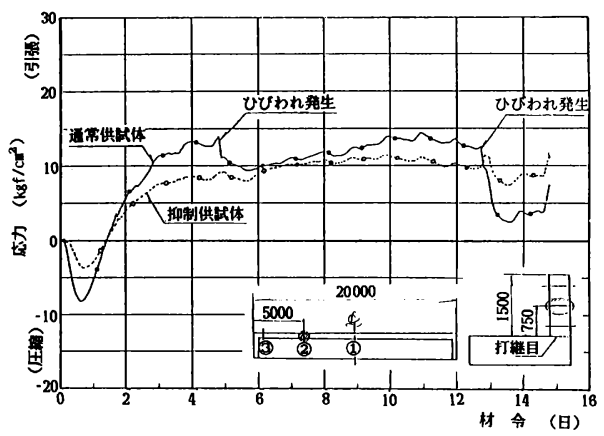

図一21 両供試体の断面(2)の中段部における発生応力

体的に発生応力が小さくなっているだけでなく, 分布状 況も大きく異なっている. すなわち, 供試体の打継目近 傍では, 打継部の遅延コンクリートの緩衝作用により底 版部の拘束が緩和されるため, 発生する引張応力も小さ くなり, 中段部で最大引張応力を生じている.

また，通常供試体のひびわれ発生時（材令 4.8 日）の 最大引張応力は $18.1 \mathrm{kgf} / \mathrm{cm}^{2}$ であり, 断面(1)の下段部 で発生している。これに対して，同時期に抑制供試体の 同位置で発生した引張応力はわずか $0.7 \mathrm{kgf} / \mathrm{cm}^{2}$ であ り, 約 96\%の応力低減効果が認如られた。しかし, 抑 制供試体の断面 (1)の中段部では,この時期に 10.0 $\mathrm{kgf} / \mathrm{cm}^{2}$ の最大引張応力が発生している.この応力は, 壁の断面内の温度差に基づく内部拘束応力と外部拘束応 力との和によるものと考えられるが, 実用上は, 本温度 応力抑制工法の適用効果をこの最大引張応力に対して評 価するのが好ましいと考えられる。いま, 通常供試体に おいてひびわれの発生がない場合, 図一21 から最大引 張応力は約 $20 \mathrm{kgf} / \mathrm{cm}^{2}$ 程度と推定される.したがって, この值と抑制供試体の最大引張応力との比較から, 本温 


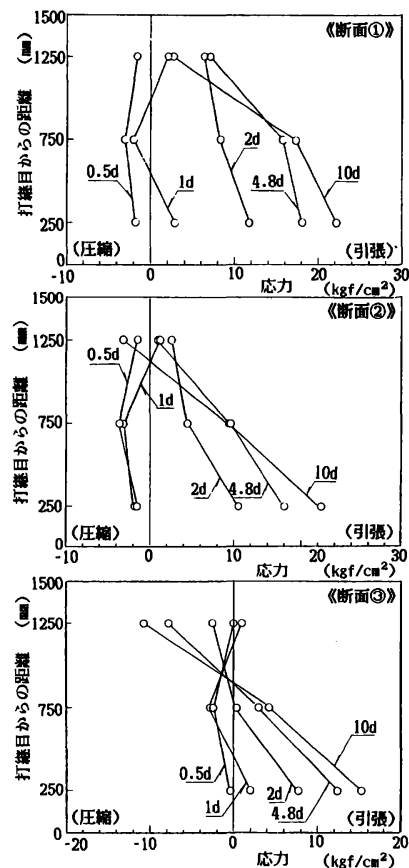

図一22 通常供試体における発生応力の分布

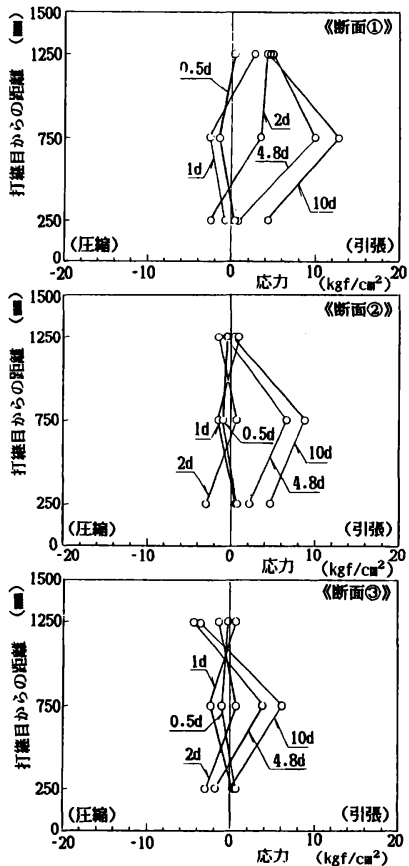

図一23抑制供試体における発生応力の分布

度応力抑制工法の適用により約 $50 \%$ の応力低減効果が あったことがわかる。

（2）新旧コンクリートの相対変位

新旧コンクリートの高さ方向および長さ方向の相対変 位の経時変化を，それぞれ図一24および図一25に示す。

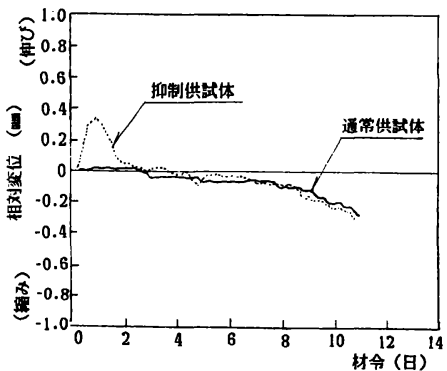

図一24 高さ方向の相対変位

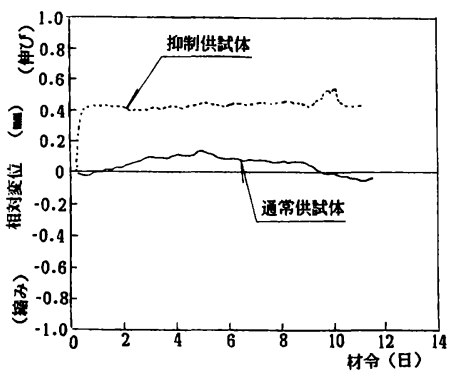

図一25 長さ方向の相対変位
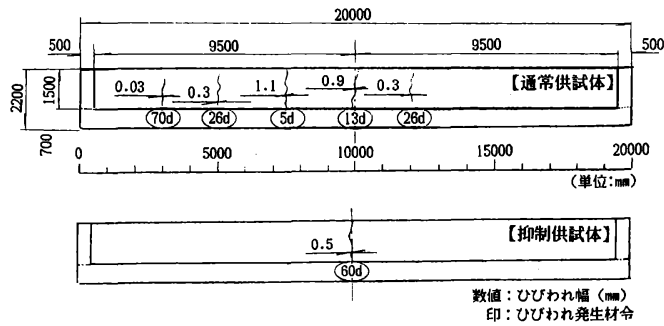

図一26＼cjkstart材令 90 日における貫通ひびわれの発生状況

これらの相対変位は，コンクリートがほぼ硬化した壁部 コンクリート打設 8 時間後からの测定值であり，それぞ れ 2 か所での測定結果の平均值を示した.

これらの図に示すように，通常供試体および抑制供試 体の相対変位は大きく異なることがわかる．すなわち， 前者の場合，新コンクリート（壁部）の変形が旧コンク リート（底版部）によって拘束されるため，実験供試体 の端部においても相対変位は小さい。一方，後者の場合 は，打継部に打設された遅延コンクリートの緩衝作用に より旧コンクリートの拘束が大きく緩和されるため，打 設初期において実験供試体の端部で大きな相対変位が生 じている。このような打設初期における新旧コンクリー トの大きな相対変位の発生により, 新コンクリートに発 生する温度応力が緩和されるものと考えられる。

\section{（3）ひびわれ観察結果}

実験供試体の型枠脱型後, 目視により壁部コンクリー トのひびわれ発生状況を観察した。図一26に，材令 90 日における両供試体の貫通ひびわれの発生状況を示す.

同図に示すように，通常供試体では材令 14 日までに 
表一7 材令 90 日における全ひびわれ幅

\begin{tabular}{|c|c|c|c|c|c|}
\hline & \multicolumn{2}{|c|}{ 黄通ひびわれ } & \multicolumn{2}{|c|}{ 0.02m虫下のひびわれ } & \multirow{2}{*}{ 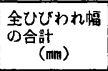 } \\
\hline & 本数 & 全ひどかれ幅(m) & 本数 & 全ひどわん幅(mm) & \\
\hline 通常供鸹体 & 5 & $2.63(1.00)$ & 41 & $0.82(1.00)$ & $3.45(1.00)$ \\
\hline 抑制共战体 & 1 & $0.50(0.19)$ & 23 & $0.46 \quad(0.46)$ & $0.96(0.28)$ \\
\hline
\end{tabular}

温度応力によるひびわれが 2 本発生し，その後材令 90 日までに新たに 3 本の貫通ひびわれが発生した。一方， 抑制供試体では材令 14 日までのひびわれの発生は認め られず，わずかに材令約 60 日で 1 本の貫通ひびわれが 観察された.

また，両供試体の表面部には，主として乾燥収縮によ ると考えられる $0.02 \mathrm{~mm}$ 以下の微小なひびわれが多く みられた，表一7は，材令 90 日での両供試体の全ひび われ幅を示したものである。同表から，本温度応力抑制 工法を適用することによって, 実験供試体の壁部コンク リートに発生する全ひびわれ幅を約 $28 \%$ に低減できる ことが認められた。

\section{（3）打継部の一体性に対する検討}

a) 打継部の止水性：本温度応力抑制工法を適用した 場合の打継部の一体性を検討する目的で, 両供試体の打 継部から水平方向に行ったコアボーリングにより採取し たテストピースを用いて，アウトプット法により透水試 験を行った. 両供試体の透水係数の長さ方向の分布を図 一27に示す.なお，透水係数は加圧後 48 時間での浸透 水量から算定した.

同図に示されるように，打継部の透水係数の分布は通

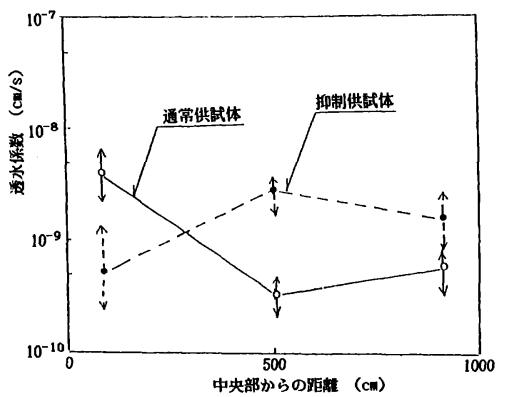

図一27透水係数の長さ方向の分布

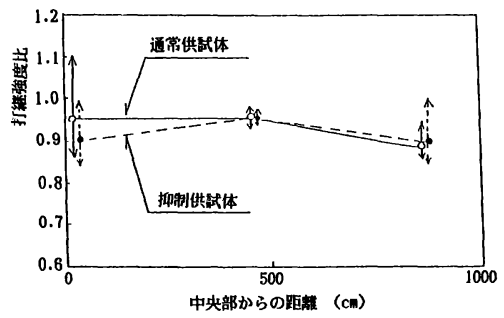

図一28 打継強度比の長さ方向の分布
常供試体と抑制供試体とで幾分異なることがわかる.す なわち, 前者は実験供試体の中央部で最も透水係数が大 きく，端部では透水係数が小さくなり，打継部の止水性 が向上する傾向にある. 一方, 後者は央験供試体の中央 部よりも端部の方が逆に透水係数が大きくなり，打継部 の止水性が低下する傾向にある．著者らがすでに行った 長さ $13 \mathrm{~m}$ の供試体を用いた実験結果によれば"11，打継 部の止水性は中央部からの距離が増加するにつれて低下 しており，通常供試体の試験結果がこのように異なった 傾向を示した原因は明確ではない。しかし，一般的に打 継部の止水性は打継部の施工方法, 特に表面処理状態, 新コンクリートの流動性および振動締固めの程度などに 大きく影響を受けること ${ }^{12\}}$, 同一位置での試験值のばら つきが比較的大きなことなどを考慮すれば，両者の差は 有意なものでなく，本温度応力抑制工法を適用した場合 の打継部の止水性は通常の打継ぎを行った場合とほぼ同 様と考えられる.

また，通常のコンクリート構造物の透水係数が $10^{-10}$ $\sim 10^{-8} \mathrm{~cm} / \mathrm{s}$ 程度であることから判断すれば, 両供試体 の打継部から得られたこれらの值は止水性に関して十分 満足できる值であり，適切な打継ぎ処理を行えば，本温 度応力抑制工法を用いても，打継部の止水性が十分確保 できることが実証された。

b) 打継強度：前述した透水試験と併せて，打継部 の構造一体性を検討する目的で, 両供試体の打継部から 鉛直方向に採取したコア供試体を用いて JIS A 1106 の 曲げ強度試験方法に準じて打継強度試験を行った。両供 試体の試験結果の比較は, 実験供試体の壁部から採取し た通常コンクリートの一体物の曲げ強度に対する各曲げ 強度の比（打継強度比）によって行った。両供試体の打 継強度比の長さ方向の分布を図一28に示す。

同図に示すように，通常供試体および抑制供試体の打 継強度比は，いずれも端部で若干小さくなる傾向にある ことがわかる．この原因としては，前述したように新旧 コンクリートの相対変位が実験供試体の端部で大きくな ることが一因と考えられるが，この端部においても打継 強度比は約 0.9 となっており, 構造強度上は問題がない ものと考えられる ${ }^{131}$.

また，通常供試体と抑制供試体の打継強度比を比較す ると, 両者の間には顕著な差は認められず，いずれの打 継方法を採用した場合でも，適切な打継処理を行うこと により十分な打継強度が得られることが確認された.

\section{4. 結論}

実規模供試体を用いた実証実験により得られた結果を 要約すると, 以下のとおりである.

（1）通常供試体においては材令 14 日までに温度応 
力によるひびわれが 2 本発生したのに対して，抑制供試 体ではこの時期までにひびわれの発生は認められず，本 温度応力抑制工法の適用により，コンクリート打設初期 の温度ひびわれの発生を防止できることが実証された。

（2）通常供試体における応力分布は，打継目近傍で 最大引張応力が生じ, 打継目からの高さが増大するのに 従い発生応力が小さくなる傾向を示した.これに対し, 抑制供試体は中段部で最大引張応力を生じ, 発生応力の 分布形状が大きく異なった。また，通常供試体の最大引 張応力が約 $20 \mathrm{kgf} / \mathrm{cm}^{2}$ と想定されたのに対し，抑制供 試体の同時期における最大引張応力は約 $10 \mathrm{kgf} / \mathrm{cm}^{2}$ 之 なっており約 $50 \%$ の応力低減効果が認められた。

（３）本温度応力抑制工法の適用により，コンクリー 卜打設初期の拘束度を大幅に低減できることが確認され た. 本実験での拘束度は温度上昇時および下降時で, そ れぞれ約 30\% および約 $50 \%$ に低減された。

(4) 両供試体の打継部において水平方向から採取し たテストピースを用いて透水試験を行った結果, 両者の 差は有意なものでなく，本温度応力抑制工法を適用した 場合でも適切な打継処理を行うことにより，打継部にお いて十分な止水性が確保できることがわかった。

（5）両供試体の打継部において鉛直方向から採取し たテストピースを用いて打継強度試験を行った結果，両 供試体の打継強度はほぼ同等となり，しかもその値は通 常コンクリートの一体物の $90 \%$ 以上となることが確認 された。したがって, 本温度応力抑制工法を適用しても 適切な打継处理を行えば, 打継部の一体性が十分確保で きることがわかった。

（6）ひびわれ発生後の有効弾性係数は大きく変化す るが，ひびわれ発生前後の拘束度をパラメーターとして 用いることにより，この前後の有効弾性係数は同様に評 価できることがわかった。

\section{5. あとがき}

凝結遅延性コンクリートを用いた温度応力抑制工法の 実構造物への適用を目的として，長さ $20 \mathrm{~m}$ の実規模供 試体を作製して実証実験を行った結果，発生応力，拘束 度およびひびわれ発生状沉などの点から, 本温度応力抑 制工法がコンクリート打設初期の温度応力低減に対し て，非常に有効な工法であることが実証された．しかし ながら，壁式コンクリート構造物では長期において，乾 燥収縮によるひびわれの発生も大きな問題となる。した がって，長期間にわたりひびわれの発生を防止するため
には，遅延効果をさらに発揮させてコンクリート打設初 期の温度応力を低減させるとともに, 高性能減水剂や収 縮低減剤などを併用して, 乾燥収縮の低減を計ることが 必要不可欠になるものと考えられる．このため，今後は これらについて引き続き検討を行いたい.

\section{参 考 文 献}

1）竹下治之：凝結遅延性コンクリートを用いた外部拘束応 力の抑制に関する研究, 土木学会論文集, 第 372 号, pp. 85 92, 1986.

2）竹下治之・横田季彦・森 時昭 - 田中恭一：凝結遅延コ ンクリートを用いた温度応力の抑制に関する研究, 第 6 回コンクリート工学年次講演会論文集, pp. 285 288, 1984.

3）村田二郎・黒井登起雄・前山光宏：超遅延性混和剂に関 する研究, セメントコンクリート, No. 385, pp. 6〜12, 1979.

4）竹下治之：超遅延剤を添加したコンクリートの基礎的特 性に関する研究, 土木学会論文集, 第 378 号, pp. 221 $229,1987$.

5）石川雅美・前田強司・西岡 哲 - 田辺忠顕：大型試験体 によるマスコンクリートの温度応力実験, 第 10 回コンク リ一ト工学年次講演会論文集, pp. 169 174, 1988.

6）田沢栄一・飯田一彦：硬化時温度応力の発生メ力ニズム について, マスコンクリートの温度応力発生メカ二ズム に関するコロキウム論文集, 日本コンクリート工学協会, pp. 101 104, 1982.

7) 日本コンクリート工学協会：マスコンクリートのひびわ れ制御指針，技報堂出版，1986.

8）青景平昌・前野宏司・伊藤祐二：大断面ボックスカル バートの硬化時温度応力について, 第 2 回マスコンクリー トの温度応力発生メカニズムに関するコロキウム論文集, 日本コンクリート工学協会, pp. 15〜20, 1984.

9）竹下治之・浅沼 潔・横田季彦：コンクリート硬化時の 有効弾性係数に関する一考察，士木学会第 41 回年次学術 講演会概要集第 5 部, pp. 381 382, 1986.

10）竹下治之・浅沼 潔・横田季彦：ボックスカルバートの 温度応力の実测と解析, 第 8 回コンクリート工学年次講 演会論文集, pp. 55 60, 1986.

11）竹下治之・横田季彦・浅沼 潔：実大モデルを用いた新 しい温度応力抑制工法の評価, 土木学会第 42 回年次学術 講演会概要集第 5 部, pp. 376 377, 1987.

12）横田季彦・竹下治之・長澤啓介：新旧コンクリートの打 継部の処理方法に関する基礎的実験，土木学会第 43 回年 次学術講演会概要集第 5 部, pp. 484 485, 1988.

13）国分正胤：新旧コンクリートの打継目に関する研究，土 木学会論文集，第 8 号, pp. 1 24, 1950.

(1990.6.4 - 受付) 